\title{
ASSISTANCE OR MANUAL AID IN SIGNING OR AFFIXING MARK TO WILLS IN PENNSYIVANIA
}

\author{
Albert Smith Faught
}

I.

During recent years the Supreme Court of Pennsylvania has rendered two decisions relating to the effect of giving manual aid to a testator in signing his name to his written will; and a third decision has been handed down on the kindred topic of the execution of a will by means of a mark. These decisions, announced in March, April and May of I927, indicate the present uncertainty of the legal profession as to the exact circumstances under which a testator may be aided in signing his will or may be allowed to execute his will by a mark or cross.

In Brehony v. Brehony, the Court of Common Pleas had tried at law an issue framed by the Orphans' Court as to whether the name of a blind testatrix had been forged because her hand had been guided by another when she signed her name at the end of her will. The jury found that the signature was a forgery, but the trial judge set aside the verdict and entered judgment in favor of the proponents. This judgment was affirmed by the Supreme Court.

The Orphans' Court in Wagner's Estate ${ }^{2}$ sustained an appeal from the Register of Wills admitting an instrument to probate, and refused to direct an issue to the Court of Common Pleas after finding that the testatrix lacked testamentary capacity, that undue influence had been used, and that the testatrix's signature was affixed with the manual aid of the chief proponent. The Supreme Court affirmed the decree of the Orphans' Court.

Finally in Carmello's Estate, ${ }^{3}$ the Orphans' Court dismissed

\footnotetext{
${ }^{1} 289$ Pa. 267, I37 Atl. 260 (1927).

2289 Pa. 36I, I37 Atl. 6I6 (I927).

${ }^{3} 289$ Pa. 554, I37 Atl. 734 (I927).
} 
an appeal from the Register of Wills, admitting a will to probate which had been signed by the scrivener in the presence of the testator, who had merely affixed thereto his mark. The Supreme Court affirmed the decree of the Orphans' Court, commenting that the inability of the testator to sign his own name by reason of physical weakness had been sufficiently shown.

II.

There should be but little doubt in the minds of either bench or bar as to the exact circumstances under which a testator may: (I) use a mark instead of a signature to a written will; (2) cause his name to be signed for him in lieu of signing the written will himself; or (3) receive manual aid in signing his name or in making his mark to his will. The answer to these questions is found in the legislative history of the various Pennsylvania statutes of wills, and in the judicial history of the meaning of the word signature as applied to testamentary instruments. Recourse to this judicial history is necessary because, as pointed out in Knox's Estate:

"the legislature not having concerned itself with what should be deemed a signing, we must look dehors the statute for a definition." 4

Mr. Justice Mitchell in Knox's Estate gives a brief resume of both the legislative and judicial history with which we are concerned, and presents a picture of the law which remained substantially unchanged until the passage of the Wills Act of IOI 7 , modifying the statutory requirements as to the execution of wills:

"The condition of the law before the passage of the wills act of 1833 is well known. By the English statute of frauds all wills as to land were required to be in writing, signed by the testator. Under this act it was held that the signature of the testator in any part of the instrument was sufficient: I Redf. on Wills, c. 6, $\S$ I 8 , pl. 9, and cases there

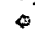

I3I Pa. 220, 229, I8 At1. IO2I, I022 (1889). This was quoted with approval in Kimmel's Estate, $278 \mathrm{~Pa}$. 435, 44I, I23 Atl. 405, 406 (1924). 
cited. The same construction was given to the law in Penn. sylvania, and under the act of I705, I Sm. L. 33, which required wills of land to be in writing, and proved by two or more credible witnesses, etc., it was even held that a writing in the hand of another, not signed by the testator at all, might be a good will: Rohrer v. Stehman, I W. 463. In this state of the law the act of 1833 was passed. It was founded on the English statute of frauds, 29 Car. II., the phraseology of which it follows closely, but with the important addition that the will shall be signed 'at the end thereof.' In making this change, it is undoubtedly true, as suggested by Strong, J., in Vernon v. Kirk, 30 Pa. 222, that the legislature 'looked less to the mode of the signature than to its place.' Accordingly, the statute makes no definition of a signature, or of the word, signed. 'It was only by judicial construction that . . ( (the statute) was made to require . . . the testator's signature by his name:' Strong, J., Vernon v. Kirk; and that judicial construction which held that a mark was not a valid signature: Asay v. Hoover, $5 \mathrm{~Pa} .2 \mathrm{I}$; Grabill v. Barr, $5 \mathrm{~Pa}$. 44I, decided in $\mathrm{I} 846$, was changed, it may be noted, by the legislature as soon as their attention was directed to it: Act January 27, I848, P. L. I6." 5

Mr. Justice Mitchell then adds:

"The purposes of the act of 1833 were accuracy in the transmission of the testator's wishes, the authentication of the instrument transmitting them, the identification of the testator, and certainty as to his completed testamentary purpose. The first was attained by requiring writing instead of mere memory of witnesses, the second and third by the signature of testator, and the last by placing the signature at the end of the instrument. The first two requirements were derived from the English statute; the third was new, (since followed by the act of I Vict. c. 26), and was the result of experience of the dangers of having mere memoranda or incomplete directions taken for the expression of final intention: Baker's App., Io7 Pa. 38I; Vernon v. Kirk, 30 Pa. 223." 6

${ }^{8}$ Ibid. 228, 18 Atl. at I022.

'Ibid. 229, 18 Atl. at I022. 
Without further elaboration it may be said that:

" "exactly what constitutes a signing has never been reduced to a judicial formula . . . whatever the testator or grantor was shown to have intended as his signature was a valid signing, no matter how imperfect or unfinished or fantastical or illegible, or even false, the separate characters or symbols he used, might be, when critically judged." " 7

Accordingly the following may constitute a signature when so intended by the signer: the first name; ${ }^{8}$ a fictitious name; ${ }^{9}$ an endorsement of figures; ${ }^{10}$ a nickname such as "father"; ${ }^{11}$ and initials where the rest of the name is impressed by a pen of which the ink has run dry. ${ }^{12}$

The closest approach to a judicial definition of a signature appears per curiam in Brennan's Estate:

"Signing in the usual acceptation of the word and in the sense in which, presumably, it is used in the act is the writing of a name or the affixing of what is meant as a signature." 13

Accordingly it is sufficient although the handwriting be illegible, ${ }^{14}$ or as in the case of the signature of Rufus Choate, "no man, unaided, could discover what the ragged marks made by (him) . . . were intended to represent." 15

While under the English Statute of Frauds marks and signatures imperceptibly grade into each other, this is no longer true in Pennsylvania; and a sharp distinction should now be drawn between a "mark or cross" and a signature. Under Section 3

'Plate's Estate, I48 Pa. 55, 60, 23 Atl. 1038 (I892). The court is quoting the lower court's opinion.

${ }^{8}$ Knox's Estate, supra note 4. (1877).

${ }^{8}$ Williamson v. Johnson, I B. \& C. I46 (I823) ; Main v. Ryder, 84 Pa. 217

${ }^{10}$ Brown v. Butchers' \& Drovers' Bank, 6 Hill 443 (N. Y. I844). (I9I4).

${ }^{11}$ Kimmel's Estate, supra note 4; Brennan's Estate, 244 Pa. 574, 9I Atl. 220

In In re Jacob's Will, 2I W. N. C. 5 Io (Reg. of Wills, Phila. I888).

${ }^{13}$ Supra note II, at 58I, 9I At1. at 222.

14 Kris's Estate, 30 Pa. Dist. I66 (1920).

${ }^{15}$ Knox's Estate, supra note 4, at 23I, I8 At1. at 1023. 
of the Wills Act of $I 9 I 7^{16}$ it is now provided that, when a testator is unable to sign his name for other reason than the extremity of his last sickness, he must nevertheless, if able to do so, make his mark or cross. As pointed out later in this article, the validity of an instrument may turn on whether particular strokes are intended as a signature or as a "mark or cross." As a means of determining whether certain strokes are intended as a signature or as a "mark or cross," evidence of the testator's habits and customs may be of controlling importance. ${ }^{17}$

\section{III.}

The able commissioners who drafted the revised laws of I9I7 relating to decedent's estates give no hint in their commentary on Section 3 of the new Wills Act that their "clarification" of Section $I$ of the Act of $1848^{18}$ made important changes in the law relating to the execution of written wills by a mark or cross.

Under the law as it stood before the codification of I9I7, a testator, although able to write his name and subscribe his signature to his will, was wholly free to execute the instrument by his mark instead of by his signature. This was the decision of the Supreme Court in Main v. Ryder, ${ }^{19}$ decided in 1877 . In the opinion it was said:

"It is contended that the Act of 1848 applies only to cases where the testator is unable to write his name by reason of want of education, and does not excuse the absence of the signature of one who is able to write. We discover nothing in the act sustaining this view. It makes no mention of insufficient education or of physical inability. It declares that form of execution as sufficient in all cases:" 20

The privilege of executing a will by a cross or mark has been taken away in all cases except when the testator is in fact

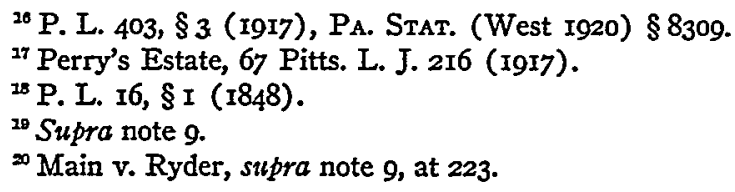


unable to sign his name. The text of Section 3 of the Wills Act of $I 9 I 7$ now reads:

"Section 3. If the testator be unable to sign his name, for any reason other than the extremity of his last sickness, a will to which his name is subscribed in his presence, by his direction and authority, and to which he makes his mark or cross, unless unable so to do,-in which case the mark or cross shall not be required,-shall be as valid as though he had signed his name thereto: Provided, That such will shall be proved by the oaths or affirmations of two or more competent witnesses." 21

Furthermore it should be noted that, as pointed out in Perry's Estate, ${ }^{22}$ the conjunctive "and" which we have italicized was substituted by the Act of I 917 for the previous disjunctive "or". Formerly a will was deemed properly executed if the testator affixed his mark, although he neither signed his name nor caused another to sign it in his presence. The writing of the testator's name was not included in the list of essential steps which must be established for the probate of a will to which the testator had affixed his mark. This appears from the opinion of Mr. Justice Walling in White's Estate, ${ }^{23}$ decided in I9I8, concerning the will of a decedent who died in I9I4:

"It is not essential to the validity of a will to prove more by the witnesses, who were present at its execution, than the identity of the instrument, that they saw the testator subscribe or make his mark, and at the time of the doing thereof he was of sound disposing mind, memory and understanding: Combs' and Hankinson's App., I05 Pa. I55."

In these two particulars, therefore, the requirements for executing a valid will were stiffened by the revised Wills Act of I9I7. Resort to a cross or mark is now permissible only when the testator is unable to sign the will; and, when the will is executed by a cross or mark, not only must the testator affix his mark or cross if able, but his name must be subscribed in his presence and by his direction and authority.

\footnotetext{
${ }^{21}$ Supra note I6. The italics are the author's.

${ }^{22}$ Supra note 17 .

${ }^{23} 262 \mathrm{~Pa}$. 356, 36I, 105 Atl. 549, 55I (r918). The italics are the author's.
} 
Yet an express request to another to sign the testator's signature is unnecessary. The "direction and authority" may be inferred from the fact that the testator saw his name written on the document or was in a position to observe the performance of this act, and knew the nature of the document which was signed in his name. The action of the testator in then placing his mark is evidence of his approval of what has been done. ${ }^{24}$

IV.

Let us next consider the question as to the effect of manual aid being given to a testator in either signing his name or affixing his mark. On this point the law is clearly established that physical assistance does not militate against the validity of the will. The recent case of Brehony $v$. Brehony, ${ }^{25}$ holding that a will is not invalidated by physical assistance in the act of its signing, is supported by McClure $v$. Redman, ${ }^{26}$ following the early case of Rees $v$. Stillé, ${ }^{27}$ in which it was said:

"That a part of the name was written with the aid of another person's holding the hand or guiding the pen does not make the signature any the less that of the alleged testator. This has many times been decided."

Nor is it necessary to prove any express request from the testator for assistance in the physical act of signing his name. ${ }^{28}$ The same holds true of the giving of manual assistance to a testator when he affixes his mark. ${ }^{29}$ His mere touching of the pen is sufficient. $^{30}$ No express request for assistance is necessary. ${ }^{31}$

${ }^{2}$ Girard Trust Co. v. Page, 282 Pa. 174, 127 Atl. 458 (1925); Hughes's Estate, 286 Pa. 466, I33 Atl. 645 (Ig26); Reilly's Estate, 9 Pa. D. \& C. 538 (1927), aff'd on another point in $92 \mathrm{~Pa}$. Super. 314 (1927); Cairn's Estate, 9 Pa. D. \& C. 5 I2 (I927).

${ }^{25}$ Supra note $\mathrm{I}$.

${ }_{26}^{263} \mathrm{~Pa}$. 405, ro7 Atl. 25 (I9I9).

${ }^{27} 38 \mathrm{~Pa}$. 138, I44 (I86r).

28 Vandruff v. Rinehart, 29 Pa. 232 (1857); Shotwell's Estate, I Pa. Dist. 257 (1892).

${ }^{20}$ Girard Trust Co. v. Page, suppra note 24 .

${ }^{30}$ Novicki v. O’Mara, $280 \mathrm{~Pa}$, 4Ir, I24 Atl. 672 (I924); Mair v. Ryder, supra note 9.

an Novicki v. O'Mara, supra note 30, citing Cozzen's Will, 6r Pa. Ig6 (1869). 


\section{V.}

Finally it should be mentioned that the privilege which a testator formerly enjoyed of expressly asking another to sign his will for him in his presence, even when the testator is himself able to sign it, has not been impaired by the revised Wills $A c t$ of 1917 . It was pointed out in Brennan's Estate, ${ }^{32}$ that:

"A testator need not sign with his own hand; he may if he choose, direct another to do so for him in his presence, and the signing is sufficient, and that too, although the testator is able to write his name."

Section 2 of the revised Wills Act of $I 9 I 7^{33}$ makes no change in the text or in the law relating to deputizing another by an express request to sign the will for the testator in his presence.

We may now answer the questions already asked as to the circumstances under which a testator may use a mark, or have his name signed for him, or receive manual aid in signing his name or making his mark to his will.

I. Since I9I7 a testator has no longer the general privilege of executing his will by his mark. He may do so only when unable to sign his name. While it is not necessary that his signature be his full name or true name, or be more than initials or some symbol which he intends as his signature, the symbol must be more than a mere cross-mark, and in case of doubt evidence of the testator's habits in using such symbol is admissible to indicate his intention. If the testator affixes a mark or cross without signing his name, his name should be signed by another in his presence and by his direction and authority. The authority may be implied and need not be an express request. The authority may be inferred from the fact that the testator saw the name written and then signified his approvai of the act by placing his mark under the signature. ${ }^{34}$

supra note II, at 578 . The quotation is from the opinion of Sando, P. J., in the Orphans' Court, 13 Lack. Jur. 229, 23I (1912), approved by the Supreme Court.

${ }^{23}$ P. L. 403, § 2 (I9I7), PA. Stat. (West I920) § 8308.

st Novicki v. O'Mara, supra note 30; Girard Trust Co. v. Page, Hughes's Estate, both supra note 24 . 
2. A testator still has the right to request another to sign the testator's name to his will in his presence, even if the testator is able to sign his own name, but the request must be an express one and not merely implied. . $^{35}$

3. The validity of the testator's act in signing his name or affixing his mark or cross is in no wise impaired by his receiving manual aid. Such assistance does not give rise to a charge of forgery. However, the testator must have sufficient testamentary capacity at the time to know what he is doing when his hand is guided in either signing his name or affixing his mark or cross. As was said by the Orphans' Court of Philadelphia in Shotwell's Estate:

"But it was her act if she knowingly accepted the aid, and this introduces the question of her mental capacity." 36

${ }^{25}$ Picconi's Estate, 4 Pa. D. \& C. 245 (1924).

"Supra note 28, at 257 . 